ANALYSIS OF AMENDMENTS AND RECOMMENDATIONS OF THE REVISION OF LEGAL ASSISTANCE LAW

\author{
Nevey Varida Ariani \\ Law And Human Rights Research And Development Agency \\ The Ministry Of Law And Human Rights \\ nevey.ariani@yahoo.com
}

\begin{abstract}
The Legal Aid Law was drafted as the legal framework for legal aid for the poor in Indonesia. The provisions of this statutory law have been in place for almost a decade. Even so, there are indications that the implementation of legal aid has not been effective in the field, both as legal aid recipients, legal aid providers, and legal aid administrators. The research problem is how the urgency of changing the Law on Legal Aid for Justice and Equality. Qualitative research methods with a normative juridical approach. The extension of legal protection includes vulnerable and marginalized groups, both witnesses and victims. Harmonization of laws and regulations so as not to cause overlaps in the implementation of legal aid, for example in the position and authority of a legal assistant. The verification period encourages the establishment of a new $\mathrm{OBH}$ in the regions. Assistance mechanisms in the form of litigation and non-litigation are not only for the perpetrators but also for the victims, both pre, process and post trial. Government support financing with a special budgeting so that it is transparent and accountable.
\end{abstract}

Keywords: Urgency, Legal Aid, Justice, Equality.

\title{
Journal History
}

Received : February 24, 2021;

Reviewed : March 24, 2021;

Accepted : April 04, 2021;

Published : April 14, 2021.

Copyright @2020 NLR. All right reserved.

\section{INTRODUCTION}

The state has an obligation to ensure access to justice and equality, to those who do not have sufficient means to pay for legal services, to equal access to justice, which in turn harms and affects vulnerable groups, hinders equality and the fulfillment of human rights, in the criteria of legal aid what is relevant is the importance of fulfilling rights and obligations as well as providing a sense of justice, certainty and legal benefits. ${ }^{1}$

The ideal role as an overarching regulation is related to the provision of legal aid to the poor. Regulations that have a role as derivative regulations from Law Number 16 of 2011 include 203-219.

\footnotetext{
${ }^{1}$ Kristel Jüriloo, "Free Legal Aid - a Human Right," Nordic Journal of Human Rights 33, no. 3 (2015):
} 
Government Regulation of the Republic of Indonesia Number 42 of 2013 concerning Terms and Procedures for Providing Legal Aid and Distribution of Legal Aid Funds, Regulation of the Minister of Law and Human Rights of the Republic of Indonesia Number 3 of 2013 concerning Procedures for Verification and Accreditation of Legal Aid Institutions or Community Organizations, as well as Regulation of the Minister of Law and Human Rights of the Republic of Indonesia Number 01 of 2018 concerning Paralegals in Legal Aid. ${ }^{2}$

The implementation of legal aid has been regulated in separate statutory provisions, however, there are several indications that the implementation of legal aid referred to in Law Number 16 of 2011 concerning Legal Aid has not been effective. Still not clearly regulating the criteria of who the parties are eligible to receive legal assistance due to the varying definitions of poor in existing laws and regulations. ${ }^{3}$ Evidence of a statement of poverty for the party receiving legal aid is in the form of a poverty statement given by the kelurahan / village.

In addition to the potential to cause confusion regarding the determination of the definition of the poor, the unclear parameter limit for the poor category which is validated only through a statement letter from the village / kelurahan has the potential to cause difficulties for legal aid recipients

2 Journal of Law, "Legal Assistance Urgention Of Volunteer Assistance, Social Workers And Buruu Unions After Return Of Ma No 22 P / Hum / 2018" 48, No. 4 (2018): 670-698.

${ }^{3}$ Nevey Varida Ariani, Implementation of Legal Aid in the Context of Access to Justice (Balitbangkumham Press, 2539). who live in an area, but are not residents registered in the area. the region. In addition, this requirement is vulnerable to being misused by recipients of legal aid who are able to finance legal aid independently. Provisions regarding legal aid should also cover vulnerable groups, for example women and children. This is because vulnerable groups are often victims of violence. $^{4}$

Based on the end of 2019 National Women's Commission (Komnas Perempuan) records, in 2018, there were an increase of 406,178 cases of violence against women reported, an increase of about $14 \%$ compared to the previous year. In the end of the year note, the realm that is most at risk of violence against women is violence in the personal sphere, namely marriage or in the household (KDRT).$^{5}$

Meanwhile, the records of the National Commission for Child Protection (KPAI) received 4,885 complaints about cases related to children in 2018. These numbers do not include violence that occurred without being reported to related agencies or law enforcement. ${ }^{6}$ The lack of legal handling of vulnerable groups leads to the need for

\footnotetext{
${ }^{4}$ Bachtiar Baital, "The Urgency of Providing Legal Aid for the Poor by Local Governments," SALAM: Syar-i 3 Social and Cultural Journal, no. 2 (2016): 137-152.

${ }^{5}$ Komnas Perempuan, Victims With Voice, Talking Data, Pass the Bill on the Elimination of Sexual Violence as a Form

State Commitment: Record of Violence Against Women in 2018, (Jakarta: Komnas Perempuan, 6 March 2019)

6 Devina Halim, Throughout 2018, KPAI Received 4,885 Cases of Violation of Children's Rights, Kompas.com, 8 January 2019, https://nasional.kompas.com/read/2019/01/08/184725 51/sepanjang-2018-kpai-terima- 4885-casesviolations-children's rights
} 
separate statutory provisions regulating the provision of legal assistance to vulnerable groups. $^{7}$

The next problem is related to the position of a paralegal in legal aid organizations, the provisions of the Regulation of the Minister of Law and Human Rights of the Republic of Indonesia Number 01 of 2018 concerning Paralegals in Providing Legal Aid. These two regulations specifically give paralegals the right to carry out legal advocacy functions in a legal aid organization, provided that the number of advocates is not equal to the number of legal aid recipients. This is considered as an act of violation of Article 2 paragraph (1) of Law Number 18 of 2003 concerning Advocates, which states that advocates have special qualification specifications in the form of graduates with a legal higher education background who have attended special education for the advocate profession organized by the Organization. Advocates, ${ }^{8}$

Law Number 16 Year 2011 concerning Legal Aid raises technical problems in $\mathrm{OBH}$ financing. Article 16 to Article 19 states that financing legal aid is the responsibility of the Ministry of Law and Human Rights. Legal aid organization financing can also come from grants and other legal and nonbinding funding sources, as well as from local government budgeting. ${ }^{9}$ The provisions in Article 20 Paragraph (1) of Government

\footnotetext{
${ }^{7}$ Accreditation Kep et al., "De Jure De Jure" 20, no. 10 (2020): 409-434.

${ }^{8}$ Law, "LEGAL ASSISTANCE URGENCY OF VOLUNTEER ASSISTANCE, SOCIAL WORKERS AND WORKERS UNIONS AFTER RETURN OF MA NO 22 P / HUM / 2018."

${ }^{9}$ Lars Waldorf, "Legal Empowerment and Horizontal Inequalities after Conflict," Journal of Development Studies, 2019.
}

Regulation Number 42 of 2013 state that the provision of legal aid per case or per activity can only be financed from the State Revenue and Expenditure Budget (APBN) and Regional Revenue and Expenditure Budget (APBD). It is known that the allocation of $\mathrm{OBH}$ funding is only Rp.5,000,000.00 (five million rupiah) per case. This amount is considered too small if it is used to handle a case from the initial stage to the final stage, as well as to carry out the functions of a legal aid organization which is not only a litigation function, but also non-litigation such as legal counseling. ${ }^{10}$

Another issue is the scope of legal aid. The Legal Aid Act divides the scope of activitiescovers civil, criminal and state administrative law issues, both litigation and non-litigation. In Article 16 paragraph (2) Government Regulation Number 42 of 2013 concerning Terms and Procedures for Providing Legal Aid and Distribution of Legal Aid Funds, it is stated that the provision of legal aid on a non-litigation basis includes the following activities: (1) legal counseling; (2) legal consultation; (3) case investigation, both electronically and non-electronically; (4) legal research; (5) mediation; (6) negotiation; (7) community empowerment; (8) assistance outside the court; and / or (9) drafting legal documents. Legal consulting activities are part of nonlitigation activities, even though legal consultation is a pre-handling step for all legal aid activities, both litigation and nonlitigation. Likewise after handling a case, it needs to be ensured that the execution of court decisions is carried out by each party,

${ }^{10}$ Baital, "The Urgency of Providing Legal Aid for the Poor by Local Governments." 
especially in civil cases such as security, bail, auction and so on. This causes OBH to have an obligation to assist him until the legal case is over, that is, if the execution of the decision is carried out in accordance with the content of the decision. In addition, access to justice for the poor or vulnerable groups is also needed when their constitutional rights are violated by laws and regulations, namely related to judicial review and the right to judicial review. that is, if the execution of the decision is carried out in accordance with the content of the decision. In addition, access to justice for the poor or vulnerable groups is also needed when their constitutional rights are violated by laws and regulations, namely related to judicial review and the right to judicial review. that is, if the execution of the decision is carried out in accordance with the content of the decision. In addition, access to justice for the poor or vulnerable groups is also needed when their constitutional rights are violated by laws and regulations, namely related to judicial review and the right to judicial review. ${ }^{11}$ Based on the formulation of the problem, in this study the urgency of changing the aid

\footnotetext{
11 Muhammad Imam Mursyidto, "URGENCY OF THE ROLE OF THE JURISDICTION TO PROVIDE LEGAL ASSISTANCE SERVICES TO THE POOR ACCORDING TO LAW NUMBER 16 OF 2011 CONCERNING LEGAL ASSISTANCE (Urgency," Implementation Science 39, no. 1 (2014): 1-15, http: //

dx.doi.org/10.1016/j.biochi.2015.03.025\%0Ahttp://d x.doi.org/10.1038/nature10402\%0Ahttp://dx.doi.org/ 10.1038/nature21059\%0Ahttp://journal.

stainkudus.ac.id/index.php/equilibrium/article/view/1 268/1127\%0Ahttp://dx.doi.org/10.1038/nrmicro2577 \%0Ahttp://.
}

law so that it can be used as a basis for changing the legal aid law.

\section{METHOD}

This study uses an empirical normative approach, which focuses on the in-action enforcement of normative legal provisions (codification, law or contract) on any particular legal event that occurs in society. ${ }^{12}$ by examining theoretical matters relating to legal principles, legal conceptions, legal views and doctrines, as well as regulations and legal systems by using secondary data in the form of laws and regulations and other regulatory regulations. This research is descriptive analytical, aims to describe the actual conditions in the field by describing systematically, factually and accurately the facts, characteristics and relationships between the phenomena investigated through the process of analysis and interpretation of the data that has been collected. $^{13}$

Primary data obtained from research informants by teleconference using the Zoom Meeting application, consisting of: 1). National Law Development Agency; 2). Regional Office of the Ministry of Law and Human Rights; 3). Legal Aid Organizations (LBH and LKBH); 4). Regional Government Legal Bureau; 5). Courts and District Attorneys; 6). State Penitentiary / Detention Center; 7). Academics 8) Police. Secondary data is obtained through literature study and secondary legal materials in the

${ }^{12}$ Abdulkadir Muhammad, Law and Legal Research, (Bandung: Citra Aditya Bakti, 2004), p. 134.

${ }^{13} \mathrm{FL}$ Whitney, The Elements of Research, (New York: Prentice Hall Inc., 1960), p. 204 
form of books, journals, related research results, and papers relevant to the research problem. This research uses qualitative analysis, which means that it describes the presentation of the data and draws conclusions. $^{14}$

\section{DISCUSSION}

\section{Legal Aid Recipients}

Ideally, apart from being aimed at economically poor communities, the provision of legal aid should be expanded to include vulnerable groups as recipients of legal aid.This is because vulnerable groups are often victims of violence. However, currently the expansion of legal aid to cover vulnerable groups is still hampered by the definition and criteria of vulnerable groups which are currently unclear. ${ }^{15}$ Therefore, expansion of legal aid recipients must be complemented by strict guidance in determining the legal aid recipients to be handled. ${ }^{16}$ Apart from being a standard indicator in determining the eligibility of legal aid recipients, this standard also aims to prevent the recipient's misuse of legal aid. In the poor category, the eligibility of legal aid recipients must be expandedto people who are more prosperous than the category of poor people according to BPS, but still in poor economic conditions such as laborers

14 B Mathew Miles and Michael Huberman, Qualitative Data Analysis, Resource Book on New Methods (Jakarta: UIP, 1992).P. 15-21.

15 Andrea Cornwall and Althea Maria Rivas, "From 'Gender Equality and' Women's Empowerment 'to Global Justice: Reclaiming a Transformative Agenda for Gender and Development," Third World Quarterly 36, no. 2 (2015): 396-415.

${ }^{16}$ Answers of Respondents at Regional Office of North Sumatra Province, 5 June 2020 with an income that does not exceed $2 \mathrm{x}$ City / Regency Minimum Wages, farmers whose land is not large, traditional fishermen and also other groups of poor people such as small traders, unemployed, and so on. ${ }^{17}$ To prevent the abuse of legal aid, OBH should be more active in screening and verifying potential legal aid recipients, both in terms of completing supporting documents (electricity bills and salary slips) as well as direct physical checks to the addresses of potential legal aid recipients. ${ }^{18}$

The expansion of the definition of legal aid recipients to include vulnerable and marginalized groups included in the material contained in the Legal Aid Bill because the Bankum Law does not yet have the same definition of this term. ${ }^{19}$ The word vulnerable has indeed been mentioned in the Law which states that everyone belonging to a vulnerable group of people has the right to receive treatment and protection with regard to their specificity. That marginalized groups can include but are not limited to persons with disabilities, commercial sex workers who experience discrimination, children and women who experience discrimination and exploitation, and people living with HIV (ADHA) and children living with HIV (PLWHA). Meanwhile, if you borrow the definition of vulnerable in Dutch law, this could consist of refugees, people

17 Leon McRae, "Severe Personality Disorder, Treatment Engagement and the Legal Aid, Sentencing and Punishment of Offenders Act 2012: What You Need to Know," Journal of Forensic Psychiatry and Psychology 27, no. 4 (2016): 476488, http://dx.doi.org/10.1080/14789949.2016.1155227.

18 Ariani, Implementation of Legal Aid in the Context of Access to Justice.

19 Ibid. 
who are homeless, national minorities, migrant workers, indigenous people, women and children. ${ }^{20}$

\section{Legal Aid Provider}

One of aspects from Legal Assistance Law, regulate about $\mathrm{OBH}$. In implementing the legal aid system, OBH plays a role in litigation and non-litigation activities, namely as a consultant, mediator, legal advisor, extension agent / resource person. ${ }^{21} \mathrm{OBH}$ handles each litigation process in one case which includes the stages of the investigation process, the prosecutor's office and the trial. There are also stages of Diversion that can occur at every level. The most common is Diversion in the Police. $\mathrm{OBH}$ in carrying out legal assistance, especially litigation assistance, starting from assisting suspects in the police, court proceedings, appeals, cassation and reconsideration), both applications for legal assistance in criminal and civil cases. ${ }^{22}$ In addition to this assistance, $\mathrm{OBH}$ also provides assistance on a non-litigation basis, namely in the form of Socialization, Empowerment, Legal Drafting, Out-ofCourt Assistance, Mediation, Investigation, Negotiation, Legal research, and consultation and making claims / requests for the community.

Currently, the provision of legal aid is often constrained by the budget aspect.

${ }^{20}$ Baital, "The Urgency of Providing Legal Aid for the Poor by Local Governments."

21 Harold Anis, "Thesis Article. Advisor: Refly Singal, SH, MH; Harold Anis, SH, MH, MSi "IV, no. 4 (2016): 144-152.

22 Mursyidto, "URGENCY OF THE ROLE OF THE JURISDICTION IN PROVIDING LEGAL ASSISTANCE SERVICES TO THE POOR ACCORDING TO LAW NUMBER 16 OF 2011 CONCERNING LEGAL ASSISTANCE (Urgency."
Apart from causing the implementation of the provision of legal aid to run less effectively, the budget factor also causes the interest of advocates to join the $\mathrm{OBH}$ to be quite minimal. Therefore, It is necessary to make improvements to budget issues for victim litigation assistance, which is currently still very minimal, because legal assistance tends to focus on suspects / defendants. ${ }^{23}$ Victim litigation assistance has a very important role in law enforcement. If the victim assistance process does not run optimally, there will be concerns that the victim will not report, the case will stop at the police level, and the victim will not get his rights. In the process of providing legal assistance, the process of victim litigation assistance that can be carried out includes assistance in making reports / complaints, assisting BAP, escorting the trial process, and submitting compensation / restitution. ${ }^{24}$

Considering the low number of registered lawyers in Indonesia, the existence of paralegals needs to be strengthened. Therefore, the role of paralegals should not be filled temporarily as at present, namely filled by prospective advocates who have not obtained certification but by parties who have been trusted by the community in providing informal legal assistance, which when referring to IJRS data consists of family, colleagues / friends, and community leaders. ${ }^{25}$ Therefore, it would be better if the paralegal recruitment process was prioritized

${ }^{23}$ Ibid
${ }^{24}$ Ibid.

25 Law, "LEGAL ASSISTANCE URGENCY OF VOLUNTEER ASSISTANCE, SOCIAL WORKERS AND WORKERS UNIONS AFTER RETURN OF MA NO 22 P / HUM / 2018." 
to the community. Paralegals also need to be equipped with adequate training in order to have a standard of ability to provide legal assistance to people or groups of poor people. This training can be facilitated by $\mathrm{OBH}$ or the Government or Local Government by strengthening the substance of understanding formal and material law, communication techniques, negotiation, mediation and other alternatives. This training is considered important because to become a paralegal, one must at least attend education, both basic education and further education. In addition, paralegals must adhere to a code of ethics.

In the process of verification and accreditation of $\mathrm{OBH}$, currently the visible condition is that the existing mechanisms are still ineffective in encouraging the establishment of new OBHs, especially outside Java.It is necessary to make changes, for example the period of verification and accreditation of $\mathrm{OBH}$ should be made every four years so that the implementation of the fulfillment of the required documents and requirements can be maximized. ${ }^{26}$ This is in line with information from the Head of the Regional Office of the Ministry of Law and Human Rights of South Kalimantan Province that the accreditation period should also be accelerated to at least two years so that the number of OBHs in the regions can be increased. $^{27}$ Apart from that it is necessary assistance is provided in the work of the $\mathrm{OBH}$ candidate before the verification and accreditation process runs. The

26 Ariani, Implementation of Legal Aid in the Context of Access to Justice.

${ }^{27}$ Head of the Regional Office of the Ministry of Law and Human Rights, South Kalimantan Province, Op. Cit. assistance that was carried out was also followed by directions for $\mathrm{OBH}$ candidates to be able to find out about matters related to verification and accreditation, so that the verification and accreditation processes would be easier to follow.

Research conducted using an analytical framework in the form of Access, Participation, Control and Monitoring (APKM), which consists of: Access, aims to determine gaps in the ease of access to justice, especially legal aid. Access can be seen from four aspects, namely: (1). Availability of legal aid facilities; (2). Geographical affordability; (3). Economic affordability; and (4). Psychic and sociocultural affordability. Participation, which aims to determine the representation of related parties as well as regional representation in legal aid, either as recipients, givers or administrators. Control, aims to determine which party determines the decisions on the allocation and use of resources related to legal aid. Benefits, aims to find out that parties involved in legal aid, in this case the recipient of legal aid, benefit from the provision of legal aid. The benefit aspect can be seen from two things, namely: (1). Practical Needs, namely needs that are immediate and based on real conditions without considering aspects of justice; and (2). Strategic Needs, namely needs based on an analysis of injustice in the provision of legal aid, and whether it is possibleto change the injustice. ${ }^{28}$

28 Attachment to Regulation of the Minister of Development of Disadvantaged Regions Number 1 of 2013 concerning Guidelines for Healthy Rural Development in Disadvantaged Areas. 
The ideal mechanism for assistance in the form of litigation and non-litigation is not only for the perpetrator but also for the victim. The implementation of legal aid is currently prioritizing litigation assistance and a larger allocation of funding for assistance for perpetrators. victims also have the right to be accompanied not only during the trial but also during pre and post trial, for example when a visum et repertum and psychological rehabilitation are conducted. "So far, the cost of a post-mortem is still being borne by the reporter / victim, in several cases where the victim is a person with hearing disabilities, the cost of translating is even to be met by the victim himself. Local government support in financing legal aid. Currently the availability of legal aid budget in APBN is very limited, even though the number of legal aid recipients continues to increase. ${ }^{29}$

\section{Legal Aid Providers}

In 2018 there were 192 new OBHs from all 864 organizations that registered and re-accredited $405 \mathrm{OBHs}$ from the 2016-2018 period. The total number of organizations that passed verification and accreditation for the 2019-2021 period was 524 OBHs spread across all provinces in Indonesia, an increase of $30 \%$ more than the previous period which was only $405 \mathrm{OBH} .^{30}$

Table 1.1 Number of Verified and Accredited OBHs per Province for the

29 Peter van Dam, "No Justice Without Charity: Humanitarianism After Empire," International History Review 0, no. 0 (2020): 1-22, https://doi.org/10.1080/07075332.2020.1739734.

${ }^{30}$ BPHN, Ibid.
Period 2018-2021

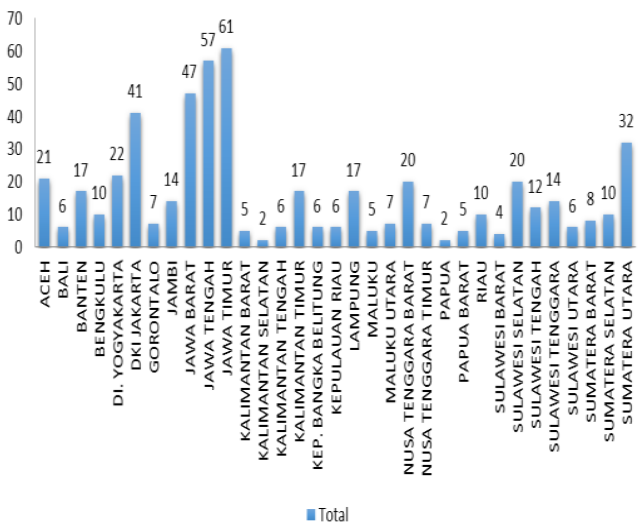

Of these, the distribution of legal aid organizations tends not to be evenly distributed in every province. There are a number of provinces that have $\mathrm{OBH}$ below fifteen, namely Jambi and Southeast Sulawesi Provinces (14 OBH); Central Sulawesi (12 OBH); Riau, South Sumatra, and Bengkulu (10 OBH); West Sumatra (8 $\mathrm{OBH})$; Gorontalo, East Nusa Tenggara, and North Maluku (7 OBH); Bali, Central Kalimantan, North Sulawesi, Riau Islands, and Bangka Belitung (6 OBH), West Kalimantan, Maluku, and West Papua (5 $\mathrm{OBH}$ ); West Sulawesi (4 OBH); and South Kalimantan and Papua $(2 \mathrm{OBH}){ }^{31}$ The majority of $\mathrm{OBH}$ is still concentrated in provincial capitals, with out of the total 514 districts / cities in Indonesia only 215 have $\mathrm{OBH} .{ }^{32}$

Separation in regulations relating to legal aid budgeting is important to do so that

31 Muhammad Yasin, This is the Distribution of Legal Aid Provider Organizations in Indonesia 2019-2021, Online Law, 28 November 2019 ,

https://www.hukumonline.com/berita/baca/lt5ddf88 0621a3a/begini-sebaran- Organizations-pemberibantuan-hukum-di-indonesia-2019-2021/, accessed March 12, 2020

${ }^{32}$ Muhammad Yasin, Ibid. 
there is a clear distinction and separation betweenbudget for litigation and nonlitigation legal aid. Between litigation and non-litigation legal aid has an important position in fulfilling access to justice, so that the financing must be equal. So that there is no judgment that non-litigation legal aid is not more important than litigation. In addition to improving the distribution of funding between litigation and non-litigation legal aid, it is necessary to make improvements related to the division of the legal aid budget portion between the Ministry of Law and Human Rights and related agencies, for example local governments. The provisions in Article 20 Paragraph (1) of Government Regulation Number 42 of 2013 state that the provision of legal assistance per case or per activity can only be financed from the State Revenue and Expenditure Budget (APBN) and Regional Revenue and Expenditure Budget (APBD). Although regulatory provisions have regulated the financing of legal aid, currently the allocation of funding for $\mathrm{OBH}$ according to the Decree of the Minister of Law and Human Rights Number M.HH03.HN.03.03 Year 2013 is still considered too minimal, which is only IDR $5,000,000.00$ (five million rupiah) per case. It is necessary to make changes to the budgeting provisions by considering the authority of the Ministry of Home Affairs to budget for the implementation of legal aid by local governments funded from the APBD. In addition, it is also necessary to regulate the financing of $\mathrm{OBH}$ originating from grant funds and other legal and nonbinding funding sources. ${ }^{33}$

Apart from budgeting, another legal framework that needs to be improved is the regulatory mechanism derived from legal aid in the regions and related agencies. Currently in several regions that have legal aid regulations, there are obstacles at the level of implementation, which are basically caused by doubts in the management and distribution of the legal aid budget. The regulation on legal aid only stops at the regional regulation level and is not followed by more technical regulations in the form of regulations or regional head decrees. The Legal Aid Law should serve as a legal umbrella for existing regulations such as Provincial Regulations and Regency / City Regulations concerning Legal Aid. Because what has happened so far is that the umbrella rules are out of sync, so that the updating rules and technical rules that are made must then be synchronized and harmonized with the umbrella rules. In this case the government's action is the most appropriate and should be done in revising Law Number 16 of 2011 concerning Legal Aid to be more comprehensive by conducting scientific studies of several regulations so that there is harmonization and synchronization. ${ }^{34}$

Proposed Amendment to Article ${ }^{35}$

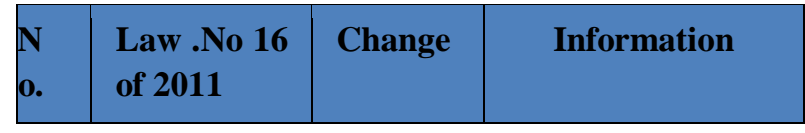

33 Baital, "The Urgency of Providing Legal Aid for the Poor by Local Governments."

${ }^{34}$ Kep et al., "De Jure De Jure."

${ }^{35}$ Ariani, Implementation of Legal Aid in the Context of Access to Justice. 


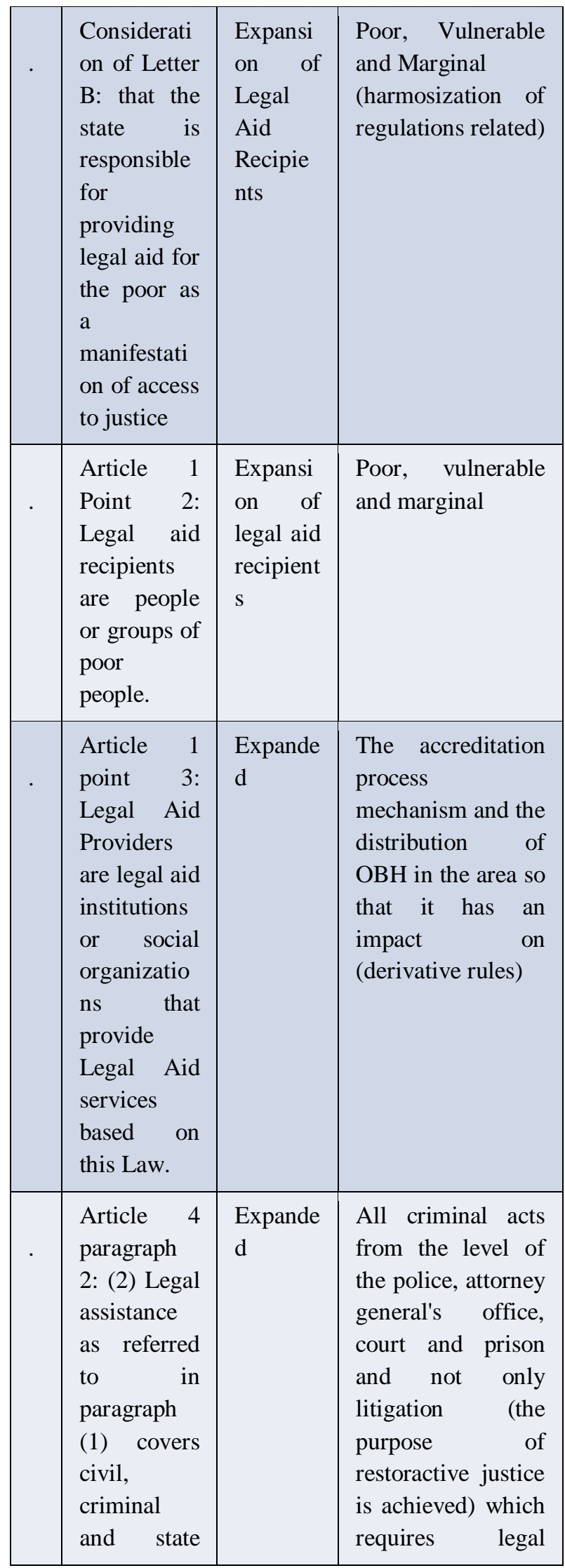

\begin{tabular}{|c|c|c|}
\hline $\begin{array}{l}\text { administrati } \\
\text { ve law } \\
\text { issues, both } \\
\text { litigation } \\
\text { and non- } \\
\text { litigation. }\end{array}$ & & services \\
\hline $\begin{array}{l}\text { Article } 4 \\
\text { paragraph } \\
2: \text { (3) (3) } \\
\text { Legal } \\
\text { assistance } \\
\text { as referred } \\
\text { to in } \\
\text { paragraph } \\
\text { (1) includes } \\
\text { exercising } \\
\text { power, } \\
\text { accompanyi } \\
\text { ng, } \\
\text { representin } \\
\mathrm{g} \text {, } \\
\text { defending, } \\
\text { and / or } \\
\text { taking other } \\
\text { legal } \\
\text { actions for } \\
\text { the legal } \\
\text { interests of } \\
\text { Legal Aid } \\
\text { Recipients. }\end{array}$ & $\begin{array}{l}\text { Affi } \\
\text { rmed }\end{array}$ & $\begin{array}{l}\text { Legal assistants so } \\
\text { as not to be } \\
\text { redundant with the } \\
\text { professionalism of } \\
\text { advocates }\end{array}$ \\
\hline $\begin{array}{l}\text { CHAPTER } \\
\text { VII } \\
\text { FUNDING } \\
\text { Article: } 16\end{array}$ & $\begin{array}{l}\text { Funding } \\
\text { mechani } \\
\text { sms } \\
\text { from } \\
\text { various } \\
\text { sources }\end{array}$ & $\begin{array}{lr}\text { Easy } & \text { and } \\
\text { accountable } & \text { aid } \\
\text { budgeting } & \\
\text { systematics } & \end{array}$ \\
\hline $\begin{array}{l}\text { CHAPTER } \\
\text { X } \\
\text { TRANSITI } \\
\text { ONAL } \\
\text { PROVISIO } \\
\text { NS: Article } \\
22 \text { The } \\
\text { administrati } \\
\text { on and }\end{array}$ & $\begin{array}{l}\text { Provide } \\
\text { space } \\
\text { for } \\
\text { resolvin } \\
\mathrm{g} \text { the } \\
\text { mechani } \\
\text { sm } \\
\text { (evaluati } \\
\text { on of } 9\end{array}$ & $\begin{array}{l}\text { Coordination } \\
\text { between Ministries } \\
\text { / Agencies The } \\
\text { effectiveness of } \\
\text { implementation in } \\
\text { the field in the } \\
\text { framework of the } \\
\text { state being present } \\
\text { for access to }\end{array}$ \\
\hline
\end{tabular}




\begin{tabular}{|c|c|c|}
\hline $\begin{array}{l}\text { budget of } \\
\text { Legal Aid } \\
\text { which is } \\
\text { administere } \\
d \text { by and is } \\
\text { at the } \\
\text { Supreme } \\
\text { Court of the } \\
\text { Republic of } \\
\text { Indonesia, } \\
\text { the National } \\
\text { Police of } \\
\text { the } \\
\text { Republic of } \\
\text { Indonesia, } \\
\text { the } \\
\text { Attorney } \\
\text { General's } \\
\text { Office of } \\
\text { the } \\
\text { Republic of } \\
\text { Indonesia, } \\
\text { and other } \\
\text { agencies at } \\
\text { the time } \\
\text { this Law } \\
\text { comes into } \\
\text { effect, will } \\
\text { continue to } \\
\text { be implemente } \\
d \text { until the } \\
\text { end of the } \\
\text { fiscal year. } \\
\text { concerned. }\end{array}$ & $\begin{array}{l}\text { years of } \\
\text { legal aid } \\
\text { impleme } \\
\text { ntation) }\end{array}$ & justice \\
\hline $\begin{array}{l}\text { Article } 24 \\
\text { At the time } \\
\text { this Law } \\
\text { comes into } \\
\text { effect, all } \\
\text { laws and } \\
\text { regulations } \\
\text { that govern } \\
\text { Legal Aid } \\
\text { are declared } \\
\text { to remain } \\
\text { valid as }\end{array}$ & $\begin{array}{l}\text { Harmon } \\
\text { ization } \\
\text { and } \\
\text { Synchro } \\
\text { nization }\end{array}$ & $\begin{array}{c}\text { Multiple } \\
\text { interpretations }\end{array}$ \\
\hline
\end{tabular}

\begin{tabular}{|l|l|l|l|}
\hline $\begin{array}{l}\text { long as they } \\
\text { do not } \\
\text { conflict the } \\
\text { with the } \\
\text { provisions } \\
\text { of this Law. }\end{array}$ & $\begin{array}{l}\text { Monitoring } \\
\text { and } \\
\text { Evaluation }\end{array}$ & $\begin{array}{l}\text { Not } \\
\text { Regulat } \\
\text { ed In the } \\
\text { Bankum } \\
\text { Law } \\
\text { (regulat } \\
\text { ed in } \\
\text { derivati } \\
\text { ve } \\
\text { regulati } \\
\text { ons }\end{array}$ & $\begin{array}{l}\text { Ruantity agrated the and } \\
\text { integrated and } \\
\text { information and } \\
\text { integrated legal aid } \\
\text { services in the } \\
\text { Criminal justice } \\
\text { System }\end{array}$ \\
\hline
\end{tabular}

That's all the point, it must change from the legal assistance law, so it will be comprehensive and effective.

\section{CONCLUSION}

Changes to Legal Aid need to be made in relation to the contents covering:Extending legal protection to include vulnerable and marginalized groups, victims who play an important role in court processes, dith the wider the reach of the bank (from the investigation stage to the court), the number of services will increaseMapping of Bankum service expansion as the basis for community legal problems. Harmonization of similar laws so as not to cause overlapping in the implementation of legal aid, such as the position and authority of paralegals (legal assistants),Paralegal services as complementary facilities for Advocates and pincreasing capacity and quality assurance for paralegals and synergy of advocates and paralegals in banking services. Encouraging the establishment of new OBHs in the 
regions, with the $\mathrm{OBH}$ verification process only being one year old,considering that the implementation of $\mathrm{PBH}$ verification and accreditation which is carried out every 3 (three) years is considered too long, while access to justice for the community is increasingly urgent. The urgency to equalize the reach of bankum services through a parallel V\&A process with increasing public knowledge about legal assistance and expanding coverage must be followed by mapping of supply and demand, territoriality and availability of $\mathrm{OBH}, \mathrm{OBH}$ outreach process for the V\&A process and guidance. Assistance mechanisms for improving the quality of bankum assistance through the preparation and application of legal aid administrative standards with a focus on encouraging bankum services in the Restoractive Justice approach (including victims and witnesses) so that it is not just a litigation process. Expansion of the Financing Mechanism by Optimizing the space for support from the Regional Government or the involvement of other parties' financing (CSR, Philanthropy, and others so that it needs to be regulated according to Bankum Program standards. It is necessary to prepare a regulatory framework with local governments using local regulations. It is necessary to elaborate the Regulatory framework for budget accountability mechanisms from other parties, including budget politics of ministries / agencies such as plegal aid budgeting orsi by the Ministry of Law and Human Rights, the Supreme Court, Local Government, and Ministries / Institutions is more transparent and accountable.

\section{REFERENCES}

Anis, Harold. "Thesis Article. Advisor: Refly Singal, SH, MH; Harold Anis, SH, MH, MSi "IV, no. 4 (2016): 144-152.

Ariani, Nevey Varida. Implementation of Legal Aid in the Context of Access to Justice. Balitbangkumham Press, 2539.

Baital, Bachtiar. "The Urgency of Providing Legal Aid for the Poor by Local Governments." SALAM: Syar-i Social and Cultural Journal 3, no. 2 (2016): 137-152.

Cornwall, Andrea, and Althea Maria Rivas.

"From 'Gender Equality and' Women's Empowerment 'to Global Justice: Reclaiming a Transformative Agenda for Gender and Development." Third World Quarterly 36, no. 2 (2015): 396-415.

van Dam, Peter. "No Justice Without Charity: Humanitarianism After Empire." International History Review 0, no. 0 (2020): 1-22. https://doi.org/10.1080/07075332.20 20.1739734 .

Law, Journal. "Legal Assistance Urgency Of Volunteer Assistance, Social Workers And Workers Unions After The Rules Of Ma No 22 P / Hum / 2018" 48, No. 4 (2018): 670-698.

Jüriloo, Kristel. "Free Legal Aid - a Human Right." Nordic Journal of Human Rights 33, no. 3 (2015): 203-219,.

Kep, Accreditation, Director General of Strengthening, Risbang Kemenristekdikti, For the Poor, 
Research Agency, and Ministry of Law. "De Jure De Jure" 20, no. 10 (2020): 409-434.

McRae, Leon. "Severe Personality Disorder, Treatment Engagement and the Legal Aid, Sentencing and Punishment of Offenders Act 2012: What You Need to Know." Journal of Forensic Psychiatry and Psychology 27, no. 4 (2016): 476488.

http://dx.doi.org/10.1080/14789949. 2016.1155227.

Miles, B Mathew, and Michael Huberman. Qualitative Data Analysis Resource Book About New Methods. Jakarta: UIP, 1992.

Mursyidto, Muhammad Imam. "Urgency Of The Role Of The Jurisdiction To Provide Legal Assistance Services To The Poor According To Law Number 16 Of 2011 Concerning Legal Assistance (Urgency." Implementation Science 39, no. 1 (2014): 1-15. Http: //dx.doi. org / 10.1016 / j.biochi.2015.03.025\%

OAhttp:

//dx.doi.org/10.1038/nature10402\%0

Ahttp:

//dx.doi.org/10.1038/nature21059\%0

Ahttp: //journal.stainkudus.ac. id / index.php / equilibrium / article / view / 1268/1127\% 0Ahttp: //dx.doi.org/10.1038/nrmicro2577\%0 Ahttp: //.

Waldorf, Lars. "Legal Empowerment and Horizontal Inequalities after Conflict." Journal of Development Studies, 2019. 